\title{
MINIMUM WAGE LEGISLATION IN GREAT BRITAIN
}

\section{By O. Kahn-FreUnd $\dagger$}

The Second World War has led to a number of important changes in the structure of British labour law. None of these changes was revolutionary in character and the legislative policy pursued both by the Coalition and Labour Governments continued to move along the traditional lines which have been characteristic of the British approach to social policy since the opening of this century. Nevertheless, the exigencies of the war and post-war situations have given rise to some novel features which are of sufficient interest from the point of view of the development of patterns of labour legislation to merit the attention of the American legal public. The object of this paper is to describe some of these new legislative principles in so far as they affect the regulation of wages and other conditions of employment, and to show how they fit into the general structure of British law. ${ }^{1}$

\section{Prevalence of Voluntary Bargaining}

Reluctance to interfere, abstemiousness and caution have been the traditional attitudes of British law towards the formulation of minimum standards of wages and conditions of employment. Where the trade unions are as strong and as united as they have been in this country for many decades, they look askance upon the intervention of the legislature and of the courts. Statutory machinery for the fixing of minimum wages, legal sanctions for the enforcement of collective agreements will, in their estimation, at best be a pis aller, a substitute for "social" sanctions, a crutch to be used until autonomous standards are able to stand on their own legs, and then to be cast away. There has been and there is in this country a remarkable measure of unanimity among employers and unions that wages and conditions of labour should be collectively regulated praeter legem, and that it is the function of the law to assist, but not to replace the voluntary bargainLondon.

$\dagger$ Professor, London School of Economics and Political Science, University of

1. The best description and analysis is Selds, Britrsh Wages Boards, A Study IN Industrial Democracy (1939). This supersedes Miss Sells' earlier work, The British Trade Boards System (1923), but has itself been overtaken by events. The present article attempts to acquaint the reader with developments which have occurred since the publication of Miss Sells' 1939 work. Chapters V to IX of the INDUSTrRaI Relations HandBook (Min. Lab. \& Nat'l Serv. 1944), contained a good survey of the legislation, but even this is already out of date. For further information, see RICHARDSON, IndUSTRIal Relations In GREAT BRITAIN (1933). The best descriptions of the wages councils system from a legal point of view are TILLYARD, THE WORKER aNd the State $39-78$ (3d ed. 1948) ; W. Mansfield Cooper, OUtlines of INDUSTRIal LAw, c. VIII (1947). 
ing mechanism built up by the two sides of the industry. The law intervenes supplendi causa - that has been its function in one way or another since the Trade Boards Act, $1909^{2}$-, it has now, under the Wages Councils Act, $1945,{ }^{3}$ been called upon to operate adjuvandi causa, but, whatever economists may say about the need for a "national wages policy," the British trade unions show little inclination to tolerate the interference of the law corrigendi causa. ${ }^{4}$

The collective agreement, concluded between one or several trade unions on one side, and-as a rule-one or several employers' associations on the other, is the primary source of rights and duties as between employer and employee. It is a source of "rights" and "duties," however, only if these terms are understood in the wide sense in which they are used by the sociological school of law. The lawyer as such will be unable to take cognisance of these agreements, unless he is willing to adopt some such definition of "law" as that suggested by Ehrlich. " The pure positivist for whom nothing is "law" save that which can ultimately be enforced by state provided sanction, must ignore the existence of the voluntary bargaining organisations which dominate British industrial relations and of the collective "contracts" which are the fruit of their labours. . But he will ignore these things at his peril: for so closely are the "legal" principles of British labour law interwoven with the "praeter legem" rules and customs, that not only the function but even the conceptual structure of the former cannot be understood without constant reference to the latter. "Voluntary" and "administrative" machinery, "collective" and "statutory" standards form one inextricable pattern.

No one in this country ever speaks of "collective contracts", no British workman would understand the slogan: "no contract, no work," for neither layman nor lawyer thinks of the collective agreement as a contract: it gives rise to no right of action in the courts. Nor are-exceptions apart-the terms of such an agreement "law" as between individual employers and employees: there is nothing in the law to prevent them from abrogating the collective terms by their contract of employment. By the Conciliation Act, $1896,{ }^{6}$ the Board of Trade (now the Ministry of Labour) ${ }^{7}$ was empowered to appoint

2. 9 EDw. VII, c. 22 [hereinafter Trade Boards Act, 1909].

3. $8 \& 9$ GEo. VI, c. 17 [hereinafter Wages Councils Act, 1945].

4. The substance of industrial relations is governed by a mixture of praeter legem custom and delegated legislation. The "law" appears as a "gloss" to customs which are not legally enforceable. It is the reverse of the interrelation between jus civile and jus honorarinm in Rome or between common law and equity in England. See MAITLAND, EQUITY, c. II (1929).

5. Emritch, Fundamental Principles of the Sociology of Law (1936).

6. 59 \& 60 VICT., c. 30 .

7. New Ministries and Secretaries Act, 1916, 6 \& 7 GEo. V, c. 68. 
conciliators and arbitrators. By the industrial Courts Act, $1919,{ }^{8}$ a standing Industrial Court was created "for the purpose of the settlement of trade disputes." 9 But neither the awards of conciliators under the Act of 1896, nor those of the Industrial Court under the 1919 Act, have any "binding" force. From a legal point of view they are mere suggestions, and no court can prevent anyone from distegarding them, yet out of 1755 awards rendered by the Industrial Court during the first twenty years of its existence, only four were disobeyed by the parties. ${ }^{10}$ The policy of keeping the main body of industrial relations out of the courts-the Industrial Court is not a "court" in the ordinary sense-was justified by the events. But the events also demonstrated the need for "legal" intervention in strictly defined and exceptional cases. This intervention proceeded along two different lines.

\section{Collective Bargaining and the Law}

The law was faced with two types of situations, easily distinguishable in theory, much less so in practice: collective regulation might fail at its inception owing to the unwillingness or inability of the employers to negotiate at all, or it might fail in its operation owing to the weakness of the bargaining organisations on either side or on both sides: federated employers or organised employees might be disloyal to the terms of the agreement or,-more important-outsiders might be too numerous and too strong to be compelled or induced to abide by the terms of the bargain.

It was impossible for the British legislator to respond to the challenge of the first type of situation by adopting the device used by the American National Labor Relations Act. ${ }^{11}$ For it was, in the most important cases, not a refusal of individual employers to negotiate with a strong and representative union which called for legislative intervention. It was the absence of effective organisations on the workers' side, the inability of union organisers to form a bargaining body, which in these industries prevented the normal collective machinery from coming into existence. Hence legal compulsion to negotiate would have been in vain: for often there was no one the employers could have negotiated with, while in other cases the indus-

8. $9 \& 10$ GEO. V, c. 69 .

9. Id. $\$ 1$.

10. See Sharp, A Study of the Practice and Procedure of Arbitration and Conciliation as a Voluntary Principle in Some Britis industries, with aN Account of State Action IN THIS FIELd (unpublished Ph. D. thesis in the University of London, 1940).

11. 49 Stat. 449 (1935), 29 U. S. C. $\$ 151$ (1947). 
try was so "scattered," the number of employers so large, their conduct so difficult to check, that a compulsion to bargain, while theoretically possible, would have been difficult to enforce in practice. $^{12}$ It was this type of situation which was met by the long series of minimum wage laws, beginning with the Trade Boards Act, 1909, and culminating in the Wages Councils Act, 1945.

The second type of case called for a different remedy: it was not until very recently that the statutory wage fixing machinery was put to the services of strengthening existing collective agreements. The method-or methods-used during the interwar period and also during the second world war, to secure the enforcement of collective agreements by "legal" means were-largely-experimental. They do not form the subject-matter of this paper. ${ }^{13}$ In an indirect way much the most significant of these methods was and is the Fair Wages clause, or, to be more precise, a whole structure of such clauses, embodied in the Fair Wages Resolutions of the House of Commons of 1891,1909 , and $1946,{ }^{14}$ in standing orders of numerous local authorities, and in a series of statutes dealing with government subsidies, grants and licences. ${ }^{15}$ These clauses, which have been discussed by the present writer elsewhere, ${ }^{16}$ are one of the cornerstones of British labour legislation. By comparing the wording of the House of Commons Resolutions of 1891, 1909, and 1946, one can trace an evolution similar to that which is reflected in the development from the Trade Boards Act, 1909, to the Trade Boards Act, 1918, and to the Wages Councils Act, 1945, i. e., from the mere prevention of "sweating" to the recognition of "commonly recognised standards" and from there to the protection of collective agreements.

The direct method of enforcing collective agreements played and continues to play a subordinate role in British law, but there stands out as a most interesting piece of legislation the Cotton Manufacturing

12. Public corporations established under nationalisation laws are placed under a duty to negotiate. See, e. g., Electricity Act, 10 \& 11 GEo. VI, c. 54 , \$ 53; Transport Act, 1947, 10 \& 11 Geo. VI, c. 49, § 95; Coal Industry Nationalisation Act, 1946, $9 \& 10$ GEo. VI, c. 59, § 46. See Robson, Nationalised Industries and Industrial Lav, 2 INDUSTRIAI LAW REv. 192 (1948). This duty would, in an appropriate case, appear to be enforceable by an order of mandamus.

13. See Tillyard and Robson, The Enforcement of the Collective Bargain in the United Kingdom, 48 EcoN. J. 15 (1938); Kahn-Freund, Collective Agreements ander War Legislation, 6 Mod. L. REv. 112 (1943).

14. For the wording of the Resolutions, see IndUstrial ReLations HandBook 133-138 (1944). For the 1946 Resolution (drafted in 1942), see CMD. No. 6399 (1946). See also Sells, British Wages Boards, A Study in Industrial DemocRACY 46 (1939).

15. For an enumeration of such statutes, see Industrial ReLAtrons HandBook 136 (1944). Add to this: Civil Aviation Act, 1946, 9 \& 10 Geo. VI, c. 70, 41.

16. Kahn-Freund, Legislation Throngh Adjudication. The Legal Aspect of Fair Wages Clauses and Recognised Conditions, 11 MoD. L. Rev. 269, 429 (1948) 
Industry (Temporary Provisions) Act, 1934, ${ }^{17}$ which-despite its name-is still in force. ${ }^{18}$ This Act was passed in order to deal with the difficulties facing trade unions and employers' organisations in the cotton weaving industry of Lancashire and the surrounding counties. During the depression of the 'thirties the undercutting of union rates by outsiders and the consequential underbidding of prices by non-federated employers became intolerable for both sides of the industry, and on neither side were the organisations sufficiently strong to overcome with the help of the normal voluntary machinery the danger threatening their existence. The workers were badly organised, the number of employers was large and individual undertakings often small and scattered. In this extreme situation organised workers and federated employers, acting together, called for the assistance of the law. The Act illustrates the cautious approach of the British legislator towards the problems of collective bargaining. Its operation is confined to the cotton manufacturing industry in a number of areas named in the Schedule. The minister may-in his discretion-by order "bring into force"19 the wage rates contained in a collective agreement, and, if he does, they will be "in force" as respects all persons employed in the industry of the class and description to which the agreement relates. The collective wage rate becomes-compulsorily-a minimum term of the individual contracts of employment, and the payment of a lower wage becomes a criminal offence. The civil sanction is directed to the contract, the penal sanction is directed to the act of performance: underpayment is a criminal offence, no matter whether or not the parties to the contract purported to contract out the collective agreement or whether or not the employee purported to waive his claim. The employer must give publicity to the order in the workshop. ${ }^{20}$ While the threefold mechanism of sanctions-civil, - penal, administrative-corresponds to the familiar scheme of British minimum wage legislation, it is in the pre-conditions of the ministerial order and in the conditions of its continued existence that we must find the original contribution of this statute to the system of industrial legislation. This Act is not designed to strengthen the hands of organised labour against organised capital or vice versa. Its tendency is to give to the organisations on both sides weapons against their disloyal members, and, above all, against outsiders. Hence the provision that the minister cannot act except upon a joint application by an employers' and a workers' organisation, both of which must be

17. 24 \& 25 Geo. V, c. 30 [hereinafter Cotton (Temporary) Act, 1934].

18. See Sells, op. cit. supra note 14, at 36, 66-69.

19. Cotton (Temporary) Act, 1934, $\$ 2$.

20. $I d . \S 3$. 
"representative", in the employers' case, of firms controlling the majority of the looms-and, in the workers' case, the majority of the persons employed. ${ }^{21}$ Moreover, as soon as either of the organisations "jumps off" and requests the minister to revoke the order (wholly or in part), the minister must do so. ${ }^{22}$ In no circumstances can the minister enforce a wage policy of his own: he cannot vary the contents of the agreement, either he makes the order or refuses to do so, tertium non datur, but he may-in certain circumstances-revoke an order of his own motion. ${ }^{23}$

This statute is highly significant: the only major enactment to make collective agreements directly enforceable leaves the relationship between organised capital and labour untouched; it affects, so to speak, the domestic aspect of industrial relations on either side. It is also significant in another respect (and much of what will have to be said below about minimum wage legislation will be an elaboration of this theme): it illustrates the extreme distrust with which the British public views the unaided efforts of civil servants in the field of industrial relations. The minister must not make an order under the Act, unless a board of three independent persons-none of them connected with the industry-has found that the two applying organisations are "representative," and unanimously reported to the minister that the making of the order is "expedient." 24 Six representatives of each of the applying organisations sit with the board "as assessors", but without a vote, and the board must consider written objections and may hear oral evidence. ${ }^{25}$ As has been said, the minister-although on an application in the prescribed form he must appoint a board ${ }^{26}$ - has an ultimate discretion whether or not he will follow a positive recommendation of the board. He has none where the board recommends not to make the order. The quasi-judicial machinery of an independent board, circumscribing the outer range of the government department's freedom of action will be met with again in the course of this article. It is a typical form of British legislation, designed to utilise the experience of voluntary bargaining for statutory purposes. $^{27}$

21. Id. $\S \S 1(1), 7(2)$. The employers' organisations must represent the majority of looms, but need not represent the majority of firms. The big employer (often the "good" employer) may require protection against large numbers of small outsiders who tend to undercut wages.

22. $I d$. $\$ 4(1)$.

23. Id. $\$ \S 4(2),(3)$.

24. Id. \$ $1(3),(4), 5(1)$.

25. Id. $\$ \$ 5(3),(4)$.

26. $I d$. $\$ 1(1)$.

27. The independent board, under the Cotton (Temporary) Act, 1934, became the prototype for the commissions of inquiry under the Wages Councils Act, 1945. This is a typical example of a statutory "pixlot" experiment. 


\section{Patterns of Minimum Wage Laws}

Legislation such as that discussed above presupposes the existence of bargaining machinery capable of producing workable collective agreements. There are, under that type of enactment, no statutory bodies charged with the formulation of conditions. All that the administration has to do is to add the sanction of the law to agreements voluntarily concluded. Much more important are those enactments which create machinery designed to establish standards and to formulate conditions. ${ }^{28}$ We enter here the field of minimum wage legislation proper. ${ }^{29}$

All these statutes-however much they may vary in detail-are species of a genus. The basic scheme is the same throughout. It is not the "minister," $i$. e. not the Civil Service, who regulates wages, holidays, etc. This task is entrusted to councils or boards ${ }^{30}$ whose members are, except in one case, appointed by the minister (i.e. the Minister of Labour, and, in the case of agriculture, the Minister of Agriculture or the Secretary of State for Scotland), but who operate independently. ${ }^{31}$ These boards or councils, known as "wage regulating authorities," 32 are composed of two elements: a number of independent or impartial members, neither active civil servants nor persons connected with the particular industry, and a number of repre-

28. The relevant statutes are: Trade Boards Act, 1909; Trade Boards Act, 1918, 8 \& 9 Geo. V, c. 32 [hereinafter Trade Boards Act, 1918] (now repealed) ; Agricultural Wages (Regulation) Act, 1924, 14 \& 15 GEo. V, c. 37; Agricultural Wages (Regulation) Act, 1940, 3 \& 4 Geo. VI, c. 17; Agricultural Wages (Regulation) Act, $1947,10 \& 11$ GEO. VI, c. 15 (now repealed); Agricultural Wages (Regulation) (Scotland) Act, 1937, 1 Evw. VIII, and 1 GEo. VI, c. 53; Agricultural Wages (Regulation) (Scotland) Act, 1947, 10 \& 11 GEo. VI, c. 47 (now repealed); Road Haulage Wages Act, 1938, $1 \& 2$ GEo. VI, c. 6 [hereinafter Road Haulage Wages Act, 1938] (now repealed as far as relevant); Holidays With Pay Act, 1938, 1 \& 2 GEo. VI, c. 70 (now repealed as far as relevant); Catering Wages Act, 1943, 6 \& 7 GEo. VI, c. 24 [hereinafter Catering Wages Act, 1943]; Wages Councils Act, 1945; Wages Councils Act, 1948, 12 \& 13 GEo. VI, c. 7 [hereinafter Wages Councils Act, 1948] ; Agricultural Wages Act, 1948, 11 \& 12 GEo. VI, c. 47 [hereinafter Agricultural Wages Act, 1948] ; Agricultural Wages (Scotland) Act, 1949.

29. The Coal Mines (Minimum Wages) Act, 1912, 2 Geo. V, c. 2, has been left out of account. It is still on the statute books, but has long ceased to be of practical importance. See RICHARDSON, InDUSTrRal RELATIONS IN GREAT BRITAIN 150 (1933); TILlyard, INDUSTRIAL LAw 67 (2d ed. 1928); SELLS, op. cit. supra note 14, at 22-24, 59-61. For the comparatively numerous decisions under the Act (all rendered between 1913 and 1916), see SLESSER AND HENDERSON, INDUSTRIAL LAw 674-676 (1924); By $\$ 89$ of the Education Act, 1944, $7 \& 8$ Gro. VI, c. 31, the "Burnham Committees" consisting of local authorities' and teachers' representatives are given statutory status. The minister can, by order, make the scales of remuneration submitted by the Committees binding and enforceable.

30. Wages Councils under the Wages Councils Acts, 1945, and 1948; Catering Wages Boards under the Catering Wages Act, 1943; the Agricultural Wages Board, the Scottish Agricultural Wages Board, and Agricultural Wages Committees under the Agricultural Wages Act, 1948; and under the Agricultural Wages (Scotland) Act, 1949 ,

31. Wages Councils Act, 1945, §1(1); Catering Wages Act, 1943, § 1(1); Agricultural Wages Act, 1948, Schedules I \& II.

32. This nomenclature was introduced by the Holidays with Pay Act, 1938, 1 \& 2 Geo. VI, c. 70. 
sentative members appointed by the minister after consultation with the employers' or workers' organisations concerned, or, in the case of agriculture, directly nominated or elected by the latter. ${ }^{33}$ The representatives on either side must be equal in number, and they must always together constitute the majority of the board. The minister may not appoint more than a stated maximum of independent members, but otherwise the size of the board is, except in the case of the Agricultural Wages Board, within his discretion. ${ }^{34}$ He must appoint one of the independent members as permanent chairman,' another may be appointed deputy chairman. ${ }^{35}$ Only independent members receive remuneration for their services, but all members obtain travelling and other allowances or a refund of expenses. ${ }^{36}$ The duration of their tenure is determined by the minister before he makes the appointment. ${ }^{37}$

This basic pattern of organisation reproduces on a statutory basis the long-established system of voluntary bargaining machinery. Even where the representative members are appointed as individuals, they are in effect usually the mouthpieces of their organisations. They enter into a legally regulated disputation assisted by the good offices of the former civil servants, economists, lawyers, etc., who as independent members constitute a neutral power. If they achieve a compromise, what emerges is in substance a collective agreement between the two sides, though in law it is a statutory order, a piece of delegated legislation, the contractual basis of which remains legally irrelevant.

The statutes which, from time to time, have set up these wage regulating authorities, have conformed to one of two patterns. Either they dealt with a particular industry and established wage fixing machinery adapted to its special needs, or they created a general framework available for any number of trades and industries and formulated the conditions under which the executive, $i$. e., the minister, is empowered to constitute councils or boards. Where Parliament used the first-the more rigid-type of organisation, the wage regulating

33. Wages Councils Act, 1945, Schedule I; Catering Wages Act, 1943, Schedule II; Agricultural Wages Act, 1948, Schedules I \& III.

34 . For the wages councils and catering wages boards the minister may appoint up to three independent members, and for the Agricultural Wages Board the Minister of Agriculture may appoint up to five "appointed" members. The agricultural wages committees have two "impartial" members and may, in addition, have an impartial chairman.

35. The Agricultural Wages Board has no permanent deputy chairman. The chairmen of the agricultural wages committees are in a special position. Their functions are not merely procedural, but more like those of industrial arbitrators. They have a second or casting vote, exercisable in case of an equality of votes. Before they vote, they may, if so authorized by a resolution of the representative members, adjourn the meeting and obtain the advice of the Agricultural Wages Board.

36. See SELLS, op. cit. supra note 14, at 84 . The arrangement is slightly different under $\$ 11$ of the Agricultural Wages Act, 1948.

37. In the case of agriculture this must be done by "Regulations." 
authority derived its existence from the statute itself. In these cases Parliament itself has answered the question whether for the industry concerned statutory intervention is required. Neither the minister nor the wage fixing organ is called upon to consider this question. The major problem of policy "in what circumstances should the law intervene" remains, as it were, inarticulate. It appears in the Parliamentary debates which precede the making of the statute; it does not appear in the statute itself. The need for a statutory minimum is the raison d'être for the existence of the statute, and therefore not required as an express justification for its application in specie. The only remaining statute of this kind is the Agricultural Wages Act, by the terms of which the Agricultural Wages Board must fix minimum time wages for agricultural workers. ${ }^{38}$ The law has developed away from this rigid type of organisation and, apart from the case of agriculture, all minimum wage fixing authorities set up by statute have given way to bodies set up by the minister in his discretion under statutory authority. ${ }^{39}$ This second-the more flexible type-of organisation is exemplified by such modern statutes as the Wages Councils Act and the Catering Wages Act. ${ }^{40}$ Under these statutes the minister is merely enabled to set up wage regulating authorities. Parliament formulates the conditions under which it intends the statutory machinery to operate. The considerations of social policy are here raised from the level of a legislative motive to that of a statutory enactment. They are recast in the shape of a legal principle circumscribing the minister's scope of action, and they acquire the fixity of an articulate norm. It is therefore this trade board (wages council) legislation which lays open to the analysis of the lawyer the trends of social policy in Britain as they developed in the course of the last forty years. It is this legislation which demonstrates that "trial and error" method, that progress from the particular to the general which is a proverbial characteristic of British statute making. It is this legislation too, which provides the sociologist with a standard example of how changes in the structure of society and of public opinion can transform the functions of an institution without affecting its essential legal framework.

38. Agricultural Wages Act, 1948, §3(2).

39. Under the Wages Councils Act, 1948, § 1, the Road Haulage Central Wages Board, set up by the Road Haulage Wages Act, 1938, has been replaced by a wages council.

40. Catering Wages Act, 1943. The Act does not apply to a particular industry, but to "all persons employed in any undertaking, or any part of an undertaking, which consists wholly or mainly in the carrying on" of catering activities, $i$. $e$. not only to hotels, restaurants, etc, but also to factory canteens, school canteens, etc., $\$ 1(2)$. Whether and how far "catering" in any sense was a "trade" within the meaning of the Trade Boards Acts was, to say the least, extremely doubtful. See $R$. v. Minister of Labour, Ex parte National Trade Defence Association and Others, [1932]
1 K. B. 1. 


\section{Minimum Wage Laws and Voluntary Negotiation}

Winston Churchill's Trade Boards Act of 1909 was designed to counteract "sweating." It applied directly to four industries then notorious for their low level of wages. ${ }^{41}$ For these four industries the government department concerned (then the Board of Trade, since 1917 the Ministry of Labour) was authorised by the Act itself to set up wage fixing bodies known as "trade boards." For other trades such boards could be established by "Provisional Order," ${ }^{42}$ if the rate of wages prevailing in any part of the trade was "exceptionally low as compared with that in other employments." ${ }^{43}$ No reference to collective agreements or voluntary negotiation machinery can be found in this statute. The wage fixing machinery was not as yet understood as an instrument to be used in order to supplement, let alone to support, collective bargaining. The statutory minimum wage was still regarded as an anomalous measure, an ultima ratio, to be applied only in the face of extreme abuses. Until the outbreak of the First World War only four trade boards were added to those originally established by the Act.

The Trade Boards Act, $1918,{ }^{44}$ passed as a result of the Whitley Reports, ${ }^{45}$ revealed a new spirit. The mechanism, first set in motion by the Act of 1909, was used for new objectives. The statute empowered the minister by "special order" 46 a greatly simplified procedure-to establish trade boards for any "specified trade," "if he was of opinion that no adequate machinery existed for the effective regulation of wages throughout the trade, and that accordingly, having regard to the rates of wages prevailing in the trade, or any part of the trade, it was expedient" to apply the Act. ${ }^{47}$ The old reference to "exceptionally low" wages was repealed. Under the guise of passing an amending statute, Parliament had put an old institution to the services of a new social purpose: no longer were the trade boards solely designed to operate in cases of glaring exploitation, but henceforward they would be a normal method of supplementing voluntary

41. Trade Boards Act, 1909, §1(1), and Schedule. See SELls, op. cit. supra note 14 , at 17.

42. A Provisional Order requires for its effectiveness a positive resolution of both Houses of Parliament.

43. Trade Boards Act, 1909, §1(2).

44. See note 2 supra.

45. During the First World War, the Reconstruction Committee on Relations between Employers and Employed under the chairmanship of J. $H$. Whitley, afterwards Speaker of the House of Commons, made five reports which formed the basis of much of the labour legislation passed after the War.

46. Trade Boards Act, 1918, \$\$1, 2, and Schedule I. A special order took effect on being made, but had to be laid before each House of Parliament. It was subject to being annulled upon address of either House presented within forty days.

47. Id. \$1(2). 
collective bargaining. Yet among the many shortcomings and almost indescribable casuistic difficulties inherent in this statute, one leaps to the eye: the criterion of intervention was the presence or absence of adequate bargaining machinery, not the presence or absence of effective collective regulation. In other words: where, in a given industry, trade unions and employers' associations had set up a joint industrial council, a conciliation board, or a similar (permanent or ad hoc) body, and this body was "adequate" to produce an "effective regulation of wages," no trade board could be established. It could not be established even if the "regulation of wages" ceased to be "effective", either because of a falling off in union membership or of memberships of the employers' organisation, or because of a growing unwillingness of the organised employers themselves to abide by the terms of the agreement concluded by their organisation.

Nevertheless, the scope given to the statutory wage fixing machinery by the Act of 1918 was wider than that required by the I. L. O. Minimum Wage-Fixing Machinery Convention of 1928 which was ratified by Great Britain and came into force in $1930 .{ }^{48}$ This Convention stands somewhere between the two British Acts of 1909 and 1918. By its terms each member state of the I. L. O. undertakes to create or maintain such machinery "for workers employed in certain of the trades or parts of trades . . . in which no arrangements exist for the effective regulation of wages by collective agreement or otherwise and wages are exceptionally low". The international convention thus combines two principles, viz. that of the subsidiary or supplementary character of statutory wage regulation and that of its "exceptional" ("anti-sweating") function. There is no trace in it of the new ideas embodied in British legislation since the Second World War.

In 1943 Parliament passed the Catering Wages Act, a statute which, despite its limited scope of application, is of great importance for the new legislative principles expressed in its terms. ${ }^{49}$ The Trade Boards Acts could not, for technical reasons inherent in the definition of a "trade," be universally applied to the catering industry, and special machinery was required in order to deal with the conditions of service of persons employed in it. Wages boards can be established for any category of catering workers in the absence of "machinery set up by agreement between organisations representing employers and workers

48. InT'L. LAB. Code, Art. 86 (1939).

49. The Act applies irrespective of whether the undertaking is carried on for profit. Catering is defined as "the supply of food or drink for immediate consumption, the provision of living accommodation for guests or lodgers or for persons employed in the undertaking," including incidental and ancillary activities. Catering Wages Act, 1943, \&1(2). 
respectively . . . for regulating those workers' remuneration and conditions of employment." Such wage boards can also be established if negotiation machinery exists, but "is not, and cannot by any improvements which it is practicable to secure, be made adequate for the regulation" of remuneration and conditions. ${ }^{50}$ So far the Act merely continues the policy of the Trade Boards Act, 1918,--apart from the reference to "conditions of employment" other than remuneration which, as will appear below, is less significant than would seem at first sight. The decisive innovation is to be found in the definition of "adequacy" of bargaining machinery for regulating remuneration and conditions. This is to depend not only on "what matters are capable of being dealt with by that machinery, but also to what extent those matters are covered by the agreements or awards arrived at or given thereunder and to what extent the practice is in accordance with those agreements or awards." 51

Here, in the writer's opinion, is a deliberate and decisive new departure in legislative policy, foreshadowing the more far-reaching reforms introduced two years later. Minimum wages (and holidays) can be laid down despite and even because of the existence of a collective agreement or award, if the practice is not in conformity with its terms. In effect, the statutory minimum wage fixing machinery can be used in order to fill the gap left by the absence of "legally" enforceable collective agreements and awards. Their contents can (in so far as wages and holidays are concerned) be re-cast in the shape of a statutory wages regulation order and thus be given the force of contractual terms as between employer and employee. The whole machinery of civil, criminal, and administrative sanctions, can be set in motion, in effect, for the enforcement of the substance of collective regulations. Those regulations as such remain praeter legem, but, where this is required, they can be remoulded into an administrative order, just as the substance of an international treaty (which, as such, is not the law of the land) can be converted into "law" by an Act of Parliament.

If the Trade Boards Act, 1918, was the outcome of the First World War, the Second War led to the passing of the Wages Councils Act, 1945, which repealed the Trade Boards Acts of 1909 and 1918. ${ }^{52}$ The "trade boards" have been re-christened as "wages councils," a change of name which is of more than symbolic significance. A "wages council" can be established under two alternative conditions. The minister may, in the first place, make an order setting up a wages council "if he is of opinion that no adequate machinery exists for the

50. Id. $\$ 4(1)$.

51. Id. $\$ 3(2)$ (emphasis added).

52. See a note by the present writer in 8 Mod. L. Rev. 68 (1943). 
effective regulation of the workers described in the Order and that, having regard to the remuneration existing among those workers, it is expedient that such a council should be established." 53 This is, of course, the basic principle of the 1918 Act, but in a new formulation. No longer is it the criterion whether machinery exists in a "trade" for the "effective regulation of wages," but the question to be asked and answered refers to a category of workers to be defined in the minister's order itself. No longer is it a "rate of wages" which has to be considered, but "remuneration," $i$. e., what is actually paid, and under what conditions payment is being earned. The whole mechanism has been made far more flexible by eliminating the rigid and cumbrous conception of a "trade," and more comprehensive by switching it over from a regulation of wage rates to a regulation of "remuneration." In the present context, however, the main interest concentrates on the second alternative set of circumstances under which the minister may act. A wages council can also be established for a category of workers on the ground that "the existing machinery for the settlement of remuneration and conditions of employment for those workers is likely to cease to exist or to be adequate for that purpose" 54 and, whether or not such machinery is, or is likely to remain, "adequate" depends, inter alia, on the tests formulated in the Act of 1943 and verbally repeated in that of $1945,{ }^{55}$ amongst which there appears the question "to what extent the practice is . . . in accordance with . . . agreements and awards." But a few words were added to the text of 1945, words which express the intention to use the statutory machinery not only as a remedy, but also as a preventive. While under the Catering Act the enforcement of collective regulations in the past has to be solely considered in order to determine whether the bargaining machinery had remained adequate, the Act of 1945 makes it incumbent on the authorities, also to decide whether the practice "is likely to be" in accordance with collective regulations. These agreements and awards, therefore, can be "embodied" in a wage regulation order, even if they have been universally observed so far, where the trend of the economic and social development in the industry is such that a lowering of the standard of actual observance of the collective terms can be anticipated in future.

Where the Wages Councils Act is thus to be used-as Mr. Bevin expressed it in the House of Commons ${ }^{56}$ as a "prop" for tottering bargaining machinery, $i$. e., where the minister acts on the second of

53. Wages Councils Act, 1945, $\S 1$ (2) (a).

54. Id. $\$ 1$ (2) (b), 2(1), 3.

55. Id. $\$ 4(6)$.

56. See 407 H. C. DEB. 78 et seq. (5th ser. 1944-1945). 
the above mentioned two alternatives, the procedure leading up to the creation of a wages council differs from the normal one. The Act, as happens unfortunately so frequently with British statutes, obscures the substantive legal principles by concealing them in a bewildering mass of procedural detail. ${ }^{57}$ The more important principles involved in these purely technical provisions will be discussed below.

A few figures and facts may perhaps illustrate the actual significance of this legislation in the life of the British nation. Thirtyseven new Boards were created in 1919, 1920, and 1921 under the 1918 Act. "The number of Boards in June, 1944, was 52, of which 40 cover Great Britain, 6 operate only in England and Wales, and 6 only in Scotland." 58 Fifty-one of these trade boards are now in operation as wages councils. Among the more important trades included in the list of trade boards the following may be mentioned: baking, cutlery, dressmaking, furniture manufacture (recently removed from the list), hollow-ware, laundry, milk distribution, rubber manufacture, shirt-making, sugar confectionery and food preserving, tobacco, and toy manufacture. The number of workers protected by this legislation was estimated at 1,200,000 in September 1939, the number of establishments on the list at the end of 1936 was 89,148 . In 1936 "approximately 70 per cent of the workpeople concerned were females." 59 Engineering and shipbuilding, cotton spinning and the woolen and worsted industries of Yorkshire, the railways and shipping, and the building industry have never been subject to minimum wage legislation, and the same is true-with one ephemeral exception which has lost its practical significance-of coal mining. The industries comprised in the list of special statutes or of trade board orders are mainly such as are characterised by the multitude and smallness of undertakings, in many instances the prevalence of homework or of female labour, and, in general, an intensive "union resistance" on the part of the workers. ${ }^{60}$

57. For a criticism of the draftsmanship of the Act see Robson, Legisaltive Draftsmanship, 17 PoL. Q. 330, 336 et seq. (1946).

58. Industrial Relattons Handbook 142 et seq., App. VI (1944).

59. Ibid.; see also RiCHARDSON, note 1 supra; SeLls, op. cit. supra note 14, passim and esp. at $48,115,219$.

60. The picture would be very different if account was taken of those provisions which control not the level of the wages but the mode of payment and the calculation of piece rates, $i$. $e$. statutes such as the Truck Acts, 1831 to 1940 ; the "particulars" clause in $\$ 112$ of the Factories Act, 1937, 1 EDw. VIII \& GEo. VI, c. 67; and the enactments dealing with "checkweighing," $e$. g., the Coal Mines Regulation Act, 1887, 50 \& 51 VICT., c. 58, and the Checkweighing in Various Industries Act, 1919, 9 \& 10 Gro. V, c. 51. Legislative intervention is more necessary to safeguard the mode of performance than to regulate the substance of the obligation of contracts of employment. The latter is more amenable to trade union control from outside. 


\section{Centralisation and De-Centralisation}

If the members of the wage regulating authorities are selected in the manner outlined above, there is no legislative guarantee that they are representative in a geographical as well as in a vocational sense. Experience shows, and good policy demands, that there should be, in matters which touch the livelihood of men and women, local as well as occupational self-government. How to prevent the controls from being too remote is a major question even in a comparatively small country like Britain. It is a difficult problem in view of the tendency towards centralisation inherent in the economic development.

Where the more flexible type of wage regulating machinery operates, this problem is of an administrative rather than of a legislative character. Under the Wages Councils Act, 1945, and under the Catering Wages Act, 1943, the minister is at liberty to limit the jurisdiction of the wages councils and boards with the help of geographical as well as other criteria, $i$. e., he may establish separate wage regulating authorities for different areas. It does not, however, appear that much use has been made of this power of decentralisation. Under the old Trade Boards Acts the boards themselves were empowered to establish "district trade committees" with limited functions, ${ }^{61}$ but this facility was very sparingly used, and the Wages Councils Act does not contain any analogous provision. It will be seen that the tendency towards centralised wage regulation which dominates voluntary collective bargaining is reflected in the statutory wage regulation organisation. It is the inevitable result of developments both in the business and in the trade union world. Nevertheless it remains true that, from a psychological point of view, local representation in the centralised bodies is desirable, but Parliament has not provided for any safeguards in this respect, and it is left to the organisations on both sides and to the minister to ensure that the representative members of the councils and boards are selected in a manner designed to give self-expression to local interests. ${ }^{62}$

There existed, however, until recently one case in which the law itself had made an attempt to secure local representation in a central wage fixing authority. This was the Road Haulage Central Wages

61. Trade Boards Act, 1909, §12. See Sells, op. cit. supra note 14, at 163, 166172. The minister may have had the power to set up trade boards on a local basis (see Amulree, Industrial Arbitration in Great Britain 157 (1929), but, apart from creating a number of boards for England and for Scotland, he did not exercise it.

62. Wages Councils may also, for certain purposes, establish committees and subcommittees (Wages Councils Act, 1945, Schedule I, No. 6), and catering wage boards may request the Minister to appoint committees (Catering Wages Act, 1943, §6, and Schedule II, No. 8). 
Board, set up under the Road Haulage Wages Act, $1938,{ }^{63}$ which has now, under the Wages Councils Act, $1948,{ }^{64}$ been abolished and replaced by a wages council. The Central Wages Board was, (and the wages council which has taken its place is), the wage regulating authority for all drivers of road goods vehicles and kindred workers in Great Britain, employed by operators using the vehicle for hire or reward. ${ }^{05}$ This is, from a British point of view, a high degree of centralisation, justified by the licensing system established for road goods vehicles by the Road and Rail Traffic Act, $1933,{ }^{66}$ and by the structure of the trade unions in the Transport industry. To obviate over-centralisation area wages boards were set up under the 1938 Act with mainly consultative functions, and entirely composed of representative, $i$. e., without "independent," members. ${ }^{67}$ These area boards served as a recruiting basis for the majority of those representing the two sides of the industry in the Central Board, $i$. e., in the actual process of wage fixing. The bulk of the representative members of the Central Board were chosen by the Minister from the area boards and after consultation with them, one employer and one worker from each of the ten English area boards and one each from the Scottish area board. There were, in addition, representative members appointed at the centre, but they formed the minority. With the repeal of the relevant provisions of the Road Haulage Central Wages Act, 1938, and the abolition of the Central Board as well as the area boards, this unique combination of vocational and geographical representation has disappeared, but it remains of interest as an institutional pattern. ${ }^{68}$

One might have expected to find a similar arrangement in the one remaining case of wage fixing machinery directly set up by statute, $i . e_{\text {. }}$ in the case of agriculture. In this industry local variations and interests would appear to be especially prominent and the need for geographical representation most urgent. Yet it is in this case that one can observe the tendency towards centralisation most clearly. The jurisdiction of the Agricultural Wages Board extends over the whole of England and Wales, and there is a separate Board for Scot-

63. $1 \& 2$ GEo. VI, c. 6.

64. $12 \& 13$ Gro. VI, c. 7.

65. For details see the Third Schedule to the Road Haulage Wages Act, 1938.

66. 23 \& 24 GEO. V, c. 53 . Under this act no one may use a goods vehicle on a road for the carriage of goods for hire or reward without an $\mathrm{A}-$ or $\mathrm{B}$-license, and no one may use such a vehicle in his own business (other than that of carrier) without a C-license. The text refers only to $A-$ and $B$-licensed vehicles.

67. See the Road Haulage Wages Act, 1938, \$§ 1, 2, and Schedules I, II. All these provisions have been repealed by the Wages Councils Act, 1948.

68. See the (repealed) First Schedule to the Road Haulage Wages Act, 1938. 
land. ${ }^{69}$ In addition agricultural wages committees have been established, as a rule one for each county. Under the original scheme laid down in the 1924 Act it was the task of the committees and not that of the Board to fix minimum wage rates for agricultural workers. ${ }^{\text {70 }}$ The Board acted as a supervisory body: it made the orders under which the decisions of the committees became effective, ${ }^{71}$ it assumed the functions of a committee which failed to fulfil them in proper time and manner, ${ }^{72}$ and it acted as a kind of appeal tribunal if requested to do so by the representative members of a committee. ${ }^{73}$ In 1940 , as a result of war conditions, a national minimum wage for agricultural workers was introduced-a significant achievement in social reform. Under the now repealed Agricultural Wages (Regulation) Amendment Act, 1940, ${ }^{74}$ the Board fixed this minimum wage as a binding directive for the committees. The committees remained the principal wage fixing authorities-in law. ${ }^{75}$ In substance the task of formulating the principles of agricultural wages policy and of translating them into action had been shifted to the centre, but the pattern of organisation and the composition of the various bodies remained unchanged. Now, under the Agricultural Wages Act, 1948, by which the earlier statutes have been repealed, the duty to fix minimum time rates and the power of fixing piece rates, holidays and holiday wage rates, and of cancelling or varying them, has been transferred to the Board. The Board makes these decisions for each county or combination of counties for which an agricultural wages committee is established, $i . e$. , in theory the Board may make different decisions for each county. ${ }^{78}$ Yet this decision is made at the centre and the local committees have merely the right to make representations. ${ }^{77}$ On the other hand, a number of secondary functions are entrusted to the committees. These are mainly connected with the adaptation of the central decisions to individual and local conditions, such as the permission to employ incapacitated workers at a rate lower than that fixed by the Board, the variation of the rents for "tied cottages" fixed by the Board, the fixing of additional piece rates for individual workers, and the general supervision of the training of "learners." 78 All these

69. Agricultural Wages Act, 1948, §1; Agricultural Wages (Scotland) Act, 1949. See, on the problem of centralisation and decentralisation in agriculture, SELLS, op. cit. supra note 14 , at $140-145$.
70. $14 \& 15$ GEo. V, c. $37, \$ 2$.
71. Id. \$3.
72. Id. $\$ 5(\mathrm{a}),(\mathrm{b})$.
73. Id. \$ 5 (c).
74. $3 \& 4$ GEO. VI, c. 17
75. Id. $\$ 2$.
76. Agricultural Wages Act, 1948, §1(1). See also Fourth Schedule, No. 5.
77. Id. $\$ 1(2)$.
78. Id. $\S 5,7(3), 8,6$. 
functions must, however, be exercised in accordance with the general directions given by the Board. ${ }^{79}$ This process of centralisation of functions, inevitable and by no means unwelcome in itself, has not, however, produced any transformation in the structure of the Board. The representative members of the Board continue to be centrally nominated or elected and the local committees have nothing to do with the constitution of the Board.

It will be seen that the criterion of organisation is functional throughout rather than local. Under the legislation now in force, the unity of the wages policy in any given industry is guaranteed throughout the country. Care has also been taken by the Wages Councils Act, 1945, and the Catering Wages Act, 1943, that there should be a measure of co-ordination as between the policies applied in various industries or branches of an industry. Under the Catering Wages Act this co-ordination is provided by the permanent Catering Wages Commission of which more will be said hereafter. ${ }^{80}$ The Wages Councils Act enables the minister to set up "central co-ordinating committees in relation to any two or more wages councils," constituted very much like the wages councils themselves, but with purely advisory functions. Their main task is to assist in the proper delimitation of the jurisdictions of the councils and to recommend to these councils the principles of policy which they are expected to pursue. ${ }^{81}$

\section{Creation and Abolition of Wage Regulating Authorities}

A legal system determined to foster the growth of voluntary bargaining cannot leave to the unfettered discretion of the civil service the extensive regulative interference with conditions of employment inherent in the power to establish wages councils and boards. It is true that, to some extent, their composition safeguards the interests of the voluntary organisations, but the mere existence of a board may and does affect the life of an industry. It may either stimulate or weaken the willingness of employers and workers to join an organisation. The new legislation has therefore set up a new mechanism for the creation of wages councils and catering wages boards, a mechanism operated partly by the civil service, partly by the voluntary organisations, and partly by independent mixed commissions.

79. $I d . \S 2(4)$.

80. Catering Wages Act, $1943, \S \S 1,2$.

81. Wages Councils Act, 1945, \$8. This will contribute to the solution of the "scope" problem, discussed SELLS, op. cit. supra note 14, at 209 et seq. 
(1) The initiative for the setting up of catering wages boards rests with a permanent body known as the Catering Wages Commission, ${ }^{82}$ a name which is a misnomer and an understatement of its functions. The commission is the prime mover in the setting up of catering wages boards, ${ }^{83}$ but it is also a permanent grand inquest into the "remuneration, conditions of employment, health (and) welfare" of all those employed in catering undertakings. ${ }^{84}$ More than that: it is what in modern British parlance could be described as a permanent statutory "working-party": it investigates and seeks to improve not only the social relations in the industry, but also its economic functioning, $i$. e., the "means for meeting the requirements of the public, including in particular the requirements of visitors from overseas, and for developing the tourist traffic."85 This is a significant new departure in English law. ${ }^{86}$ One body deals with social reform and encourages commercial development. Parliament has recognised and proclaimed that the welfare of the employees and the satisfactory organisation and working of the industry hang together.

The Commission has a permanent salaried chairman and two further independent members. ${ }^{87}$ In addition it has a maximum of two representative members each on the employers' and on the workers' side, appointed after consultation with organisations on both sides. They must be "qualified to represent the view of employers and workers respectively," but-and this is decisive-they must not be "directly connected with the hotel and catering trades." 88 The pattern of the "board" which advises the minister under the Cotton Manufacturing Industry Act recurs here in a different context: like this "board," the Catering Wages Commission is not an organ of collective bargaining or of wage regulation. It should look at the industry from outside, not from inside, as part of the economic life of the nation, not as the battlefield of social conflicts. Hence the employer-employee relationship as a general phenomenon is reproduced in the Commission, but not the specific tension that affects the wages and other conditions under discussion. The representation of employers' and employees' interests in general ensures, so to speak, the dialectical treatment of social questions on a higher level: the representative members are parties, "thesis" and "antithesis" in their general outlook, butideally-neutral towards the specific problems they have been appointed to solve.

82. Catering Wages Act, 1943, § 1 .

83. $I d$. $\$ 4$.

84. Id. $\$ \S 2(1)(\mathrm{a})$ and (c).

85. Id. $\S 2(1)(\mathrm{b})$.

86. There was a precedent in the Road Haulage Wages Act, 1938, §2(1) (b).

87. Catering Wages Act, 1943 , Schedule I.

88. Experts may assist the Commission as assessors without vote. 
No catering wages board can be established or abolished by the minister without a recommendation by the Commission. On the other hand, the minister need not act on the recommendation. The initiative does not rest with him, the ultimate decision does. ${ }^{89}$

(2) Under the Wages Councils Act, however, there is nothing to correspond to the Catering Wages Commission. Hence, the initiative for creating wages councils, is shared between the minister and the voluntary organisations. Where the minister desires to fill a gap left by the absence of voluntary machinery, the organisations on both sides are less vitally concerned than where the prospective council is to act as a "prop for tottering negotiation machinery." In the case of absence as well as in the case of the threatened disappearance of bargaining machinery the minister may take the first step, but in the latter case this is not envisaged as the normal procedure. ${ }^{90}$ As a rule an application will be made for the creation of a wages council. The "tottering" joint industrial council, conciliation board, etc., may, if it is established by representative organisations on both sides, apply. ${ }^{91}$ So may the organisations themselves-provided they "habitually take part in the settlement of remuneration and conditions of employment." But-again we are reminded of the Cotton Act-the employers cannot wield this instrument for the re-inforcement of collective bargaining against the workers, nor the workers against the employers. They must join together when they approach the minister-either ad hoc or in the more permanent form of a conciliation board, etc.-and may thus secure additional strength against recalcitrant members or outsiders on both sides. ${ }^{92}$ Other organisations or joint industrial councils and similar bodies interested in the matter must be consulted by the minister. ${ }^{93}$

As a further precaution, the Wages Councils Act, following in the footsteps of the Cotton Act and the Catering Wages Act, has provided for "commissions of inquiry." These are replicas of the Catering Wages Commission-their representative members must not be connected with the subject-matter of the investigation-but they are appointed $a d$ hoc and have no permanent chairman. ${ }^{94}$ If the minister proposes to establish a wages council on the ground that collective bargaining in an industry is likely to fail, he must summon a commission

89. $\$ \$ 4(3), 5(1)$. This too reproduces the pattern of the Cotton (Temporary) Act, 1934.

90. Wages Councils Act, 1945, §§1(2) (a), 3.

91. Id. $\S 2(1)(\mathrm{a})$.

92. Id. $\S 2(1)(\mathrm{b})$.

93. $I d . \S 2(3)$.

94. Id. Schedule II. 
of inquiry. ${ }^{95} \mathrm{He}$ cannot, on this ground, set up wage fixing machinery without a positive recommendation from the commission though, he may refuse to act upon it. If, however, he wants to modify the recommendation in any important respect, he must first refer it back-a course of action which might meet with difficulties in practice in view of the transient nature of the commission. ${ }^{96}$

A commission of inquiry may, but need not be consulted if the proposed wages council is designed to fill a gap left by the absence of voluntary bargaining machinery-in this case the need for additional safeguards is less urgent-but the procedure is compulsory where such machinery exists but is threatened with failure, no matter whether the minister acts proprio motu or on application. ${ }^{97}$ In the latter case the minister has very little discretion. He cannot go into the merits of the case. An application which establishes a prima facie case compels him to submit the matter to a commission of inquiry, unless the organisations fail to establish their locus standi, $i$. e., to satisfy the minister that they are of a type qualified to apply. ${ }^{98}$

Since the entire machinery of statutory wage regulation is subsidiary to voluntary collective bargaining, joint industrial councils and similar bodies or representative organisations on both sides acting jointly may apply to the minister for the abolition of a wages council, on the ground that they provide voluntary machinery "which is, and is likely to remain, adequate." Unless the minister accedes to such a request, he must refer it to a commission of inquiry. Statutory machinery should not survive the advent of voluntary bargaining. When the building is under roof, the scaffolding must be pulled down. ${ }^{99}$

(3) For many years, it has been the policy of British legislation to use official institutions in order to stimulate and improve collective bargaining. This policy can be traced back into the 19th century, and permeates the modern statutes from the Conciliation Act, 1896, onwards. ${ }^{100}$ Under the new legislation the Catering Wages Commission and the commissions of inquiry have been enlisted in support of this policy. If these bodies find that the collective bargaining system they are scrutinising is not satisfactory, but "can by improvements which it

95. Id. $\S \S 1(2)(\mathrm{b}), 2(2)(\mathrm{a}), 3,4(4)$.

96. Id. $\S \S 4(5), 9(3)$ and (4); cf. Catering Wages Act, 1943, $\S 4(4)$.

97. Wages Councils Act, 1945, $\$ 1$.

98. Id. 2 (2). Compare Sells, op. cit. supra note 14, c. IV, for a description of the System under the Trade Boards Acts.

99. $\S 6(2)$, as amended by $\S 4$ of the Wages Councils Act, 1948. This happened recently in the case of the wages council for the furniture trade. The minister may also, of his own motion, abolish, or vary the jurisdiction of, a wages council. See $\S 6(1)$.

100. See note 6 supra. 
is practicable to secure" be made adequate, they will, instead of recommending a wages council or board, suggest such improvements to the minister who must try to see that they are implemented. ${ }^{101}$ If he fails in this, the immense advantage gained by the existence of a permanent body under the Catering Wages Act becomes apparent: the matter will simply be referred back to the Commission with the minister's observations for further report. ${ }^{102}$ Under the Wages Councils Act the matter is at an end, unless the minister initiates proceedings de novo, including possibly the summoning of a fresh commission of inquiry.

The commissions of inquiry consider not only the subject matter expressly submitted to them, but "any other question or matter . . . relevant thereto." They may thus, of their own initiative, recommend a wages council or the improvement of voluntary machinery for those whose work is "complementary, subsidiary or closely allied" to that mentioned in the reference. The benefits of this legislation may thus be extended to small and scattered groups of workers, "forgotten men," whose unions are not sufficiently interested in them to set the Act in motion in their favour. The general jurisdiction of the Catering Wages Commission covers these matters, but the power vested in the commissions of inquiry of giving a wide interpretation to their terms of reference may partly make up for the lack of a permanent organisation under the Act of $1945 .^{103}$

(4) At various stages of the proceedings the outside public must be given an opportunity to be heard. Thus, commissions of inquiry under the 1945 Act and the Catering Wages Commission must publish a notice stating the questions under consideration, and must consider written representations made within a stated period. ${ }^{104}$ Objections by outsiders can again be raised-under the 1945, not under the 1943 Act-before the minister makes the order the draft of which must be laid open to public inspection. ${ }^{105}$ The Order itself is laid before Parliament for forty days. It can be annulled by a resolution of either House. ${ }^{106}$ These are, what one may call, the classical safeguards against administrative transgression. Although they were rather prominent in the debates in the House of Commons which preceded the passing of the 1945 Act, one may surmise that the new system of (3).

101. Catering Wages Act, 1943, $\S 3(1)$; Wages Councils Act, 1945, $\S \$ 4(2)$ and

102. Catering Wages Act, $1943, \S 3(2)$.

103. Wages Councils Act, 1945, §4(1).

104. Catering Wages Act, 1943, §4(2); Wages Councils Act, 1945, §8(2).

105. Wages Councils Act, 1945, $\$ 5$.

106. Catering Wages Act, 1943, §16; Wages Councils Act, 1945, $\S 21$ and (as to publication) $\S 5(5)$. 
"collective" safeguards will, in the operation of this legislation, prove a more powerful and effective method of bringing public opinion to bear on the administration of these statutes. The Catering Wages Commission submit to the minister an annual report of their proceedings which is also laid before Parliament. ${ }^{107}$

\section{JURISDICTION}

For the jurisdiction and functions of wage regulating authorities, no less than for their composition, a fairly uniform pattern has been evolved in the course of the last forty years, but recent statutes have made these bodies more flexible and have removed a great deal of the casuistry with which their action used to be encumbered.

(1) The jurisdiction of a wages council, unlike that of one of the defunct trade boards, refers to "specified workers" and no longer, as has been mentioned, to a "specified trade." Thus orders may be made regulating the remuneration of workers scattered over various industries. ${ }^{108}$ The criterion of delimitation may be the type of work, the type of employer, or the locality. The same is true under the Catering Wages Act, except that the order must refer to persons employed in an undertaking or part of an undertaking which carries on the business of catering. ${ }^{109}$ The Agricultural Wages Board can only make orders affecting workers in agriculture (a term whose definition was recently very much extended) in a given county, ${ }^{110}$ but it may subdivide the workers subject to its jurisdiction into as many categories as it thinks fit, ratione loci or ratione materiae or both. ${ }^{111}$ Even this centralised machinery can hardly be accused of not being adaptable to varying local and industrial conditions.

(2) None of the statutory authorities dealt with in this paper has ever been used for the realisation of "fair labour standards" generally. Working hours, for example, are outside their jurisdiction. Where

107. Catering Wages Act, 1943, §2(1) (d).

108. Compare Wages Councils Act, $1945, \S 1(1)$, with Trade Boards Act, 1909, $\S 1$, and with Trade Boards Act, 1918, $\S 1$. Within a "trade" the Trade Boards were empowered to fix minimum rates for special processes, areas, and classes of workers, Trade Boards Act, 1909, $\$ 4(1)$. There is now no need to go into the difficulties connected with the definition of a "trade." See the conflicting opinions in R. v. Minister of Labour, [1932] 1 K. B. 1, and in Skinner v. Breach, [1927] 2 K. B. 221. There is now no reason why wages councils should be unable to fix differential remuneration for the workers of a named employer, which is what Humphreys, J., in R. v. National Arbitration Tribunal, [1942] 2 All Eng. 162, 168 (K. B.), said trade boards were not in a position to do.

109. Catering Wages Act, 1943, §1(1).

110. Agriculture Wages Act, 1948, $\$ 17(1)$.

111. Id. at Schedule IV. 
it was intended to establish working hours maxima, this was done by direct legislation, ${ }^{112}$ but in the vast majority of cases the working hours of adult males are regulated by collective agreements. Catering wages boards may fix "intervals for meals or rest," 113 and all wage regulating authorities can indirectly exercise a strong influence on the "normal working day" by fixing overtime rates and laying down the conditions under which they are earned. ${ }^{114}$ Otherwise they are encouraged to investigate, report on and make recommendations for the improvement of working conditions, health and welfare in general, without, however, being able to lay down or to propose any binding rules in these respects. Wages councils must report on such matters upon the request of a government department, and a catering wages board may report to the Commission which transmits such recommendations to the department concerned after having consulted other wages boards and such joint industrial councils as have been approved as "adequate" by the Commission itself. ${ }^{115}$

The agricultural wages committees have recently been enabled to secure that learners in agriculture receive adequate instruction and that the terms of their employment are in other respects satisfactory. The sanction of this norm is provided by a rule that the committee may withdraw the employer's privilege to pay the (lower) minimum rate for learners if he fails to comply with the conditions imposed by the committee: the power of fixing differential wage rates thus becomes the instrument for the regulation of conditions of employment and training in general. ${ }^{116}$

(3) The proper province of the councils' and boards' activities is the regulation of remuneration, of holidays, and of holiday remuneration. It is here that radical changes were made in the law in the last few years.

The most important of these changes was the transition from the fixing of wage rates to that of "remuneration." Under the Trade Boards Acts the statutory bodies were able only to fix time rates of

112. E. g., for women and young persons, by the Factories Act, 1937, 1 Geo. VI, c. 67; Shops Act, 1934, $24 \& 25$ Geo. V, c. 42; and Coal Mines Act, 1911, 162 Geo. V, c. 50 ; and, for adult males, by the Coal Mines Regulation Act, 1908, 8 Evw. VI,
c. 57 (as amended).

113. Catering Wages Act, 1943, $\S 8(1)$ (b).

114. The power to fix overtime rates and the conditions under which they are earned was conferred upon the trade boards by the Act of 1918, $\$ 3(1)$, and is now inherent in the power of the wages councils and catering wages boards to fix remuneration. For the corresponding power of the Agricultural Wages Board see Agricultural Wages Act, 1948, \$ 3(4). Compare SELLS, op. cit supra note 14, at 290 et seq.

115. Wages Councils Act, 1945, §7(2); Catering Wages Act, $\S 6(3)$, (4), (5).

116. Agricultural Wages Act, 1948, $\S 6$. See for the control of apprenticeship by trade boards, SELLs, op. cit. supra note 14, at 190-195. 
various kinds (including over-time rates) and piece rates. In other words they could merely say: during such and such a time unit (usually an hour) of work actually done, or for so many pieces of work actually performed this category of workers must at least earn so much. ${ }^{117}$ They had no power to lay down the conditions under which the employer or the worker bore the risk of impossibility of performance (e. g., on the ground of illness, lack of fuel, lack of raw materials, weather conditions etc.), no power to vouchsafe to the worker a guaranteed minimum of remuneration for any given period (e. g., a week) irrespective of the quantity of work done, no power to compel employers to remunerate workers for their preparedness to do work frustrated by events for which the workers were not responsible, except in cases in which workers were on the employers' premises waiting for work. ${ }^{118}$ The Agricultural Wages (Regulation) Act, 1924 , was based on the same rigid system of wage-rate regulation. ${ }^{119}$ The first statute to replace it by a power to fix "remuneration" was the Road Haulage Wages Act, 1938, ${ }^{120}$ but it was the development of British labour law during the Second World War which inaugurated a general change. The Essential Work Orders ${ }^{121}$ under which the labour market was organised during the War tied the worker to the job, but protected him, on the other hand, against dismissal. Under these Orders he enjoyed the benefit of the "guaranteed week," $i$. e., of a guaranteed weekly remuneration payable by the employer irrespective of the work performed or the worker's preparedness to do it. The Catering Wages Act, 1943, and the Wages Councils Act, 1945, empower the boards and councils to fix "the remuneration to be paid either generally or for any particular work," 122 and a similar power has now, by the Act of 1948, been conferred on the Agricultural Wages Board. ${ }^{123}$ The principle of the "guaranteed week," which is rapidly gaining ground in voluntary collective agreements, can thus be given statutory force, despite the fact that the wartime system of tying to the job has now disappeared. The common lawyers, interested in the problems of frustration and impossibility of performance and in the general question of the distribution of contractual risks, should perhaps pay closer attention to these new developments than they seem to have done so far.

117. Trade Boards Act, 1909, §4; Trade Boards Act, 1918, § 3.

118. Trade Boards Act, 1918, \&8. The economic importance of these matters is analysed by SELIS, op. cit. supra note 14 , at 228 and 327.

119. Agricultural Wages (Regulation) Act, 1924, 14 \& 15 Geo. V, c. $37, \S 2$.

120. Road Haulage Wages Act, 1938, \&2(1) (e) (now repealed).

121. See S. R. \& O., 1942, No. 1594.

122. Catering Wages Act, 1943, \$ 8(1) (a); Wages Councils Act, 1945, $\$ 10$ (1) (a).

123. Agricultural Wages Act, 1948, \$ 3(3), re-enacting $\$ 1(3)$ of the Agricultural Wages (Regulation) Act, 1947, 10 \& 11 GEo. VI, c. 15. 
A number of ancillary problems arise from the regulation of wages, problems which loom very large in the practice of the statutory bodies, but can only be slightly touched upon in this paper. Elaborate provisions have been enacted with a view to enabling wages councils, catering wages board and agricultural wages committees to grant exemption permits to workers incapable of earning the statutory remuneration owing to infirmity or physical incapacity, and to fix minimum wages for such workers-provisions designed to remove from the statutory machinery the reproach of inflexibility which is sometimes levelled against it. ${ }^{\mathbf{1 2 4}}$

The problem of permissible deductions is of great complexity and bound up with the intricate British Anti-Truck legislation, with income tax and social insurance, with voluntary superannuation and thrift schemes, and, above all, with the vital question of the valuation to be placed on "benefits and advantages" granted to the worker by the employer. The importance attached to these matters emerges from the debates in the House of Commons preceding the passing of the Wages Council Act: the relevant clause of the Bill was subject to more far reaching amendments in Committee than any other part of the measure, and, as it now stands, the Wages Councils Act provides a much more detailed code governing "authorised deductions" than any of the other relevant statutes. ${ }^{125}$ It is, however, in agriculture that this topic is especially important: the definition of benefits and advantages deductible from the cash wages of agricultural workers and their valuation has always been one of the principal functions of agricultural wages committees under statutory powers which have now been transferred to the Board. ${ }^{126}$ The committees have, however, retained what is, in practice, perhaps the most significant part of their activities in this respect, the right to define the value of a tied agricultural labourer's cottage and thus the amount of rent the landlord or farmer may deduct from the minimum wage. ${ }^{127}$ Employers subject to the Wages Councils Act and to the Agricultural Wages Act may notas a rule-receive premiums from or on behalf or account of apprentices or learners, except with the approval of the relevant statutory body, and contravention of this prohibition gives rise not only to a

124. Wages Councils Act, 1945, $\$ 12$; Catering Wages Act, 1943, $\$ 9(4)(5)$; Agricultural Wages Act, 1948, \$5. See SELLS, op. cit. supra note 14, at 183-186.

125. Wages Councils Act, 1945, $\S 13$ which should be compared with Clause 13 of the Government Bill. The effect of the amendment was, inter alia, to enable the employers to make a number of deductions, $e . g$., for fines, damages, the supply of materials and tools, etc., provided a number of precautions as to form of contract, etc., are complied with. See also Catering Wages Act, 1943, §10.

126. Agricultural Wages Act, 1948, \$7.

127. Id. $\S 7(3)$. 
criminal prosecution but also to a statutory quasi-contractual civil action for recovery. ${ }^{128}$

(4) The movement for "holidays with pay" made rapid headway after the First World War. It is now the universal practice for collective agreements to make provision for paid vacations. ${ }^{129}$ The Holidays with Pay Act, 1938, enables the Minister of Labour to "approve" such voluntary schemes, to second officers of the Ministry to assist in their administration and to grant financial help by way of loans. ${ }^{130}$ The holidays with pay movement could not fail to lead to an extension of the jurisdiction of the statutory wage regulating authorities. The Road Haulage Wages Act, 1938, gave the Central Board the power to fix "holiday remuneration," 131 i. e., the amount payable in the event of holidays being granted, but it was the Holidays with Pay Act, 1938 which conferred on all statutory authorities the power to fix a minimum duration for paid holidays and the remuneration payable for them. ${ }^{132}$ This power-now exercised by wages councils, catering wages boards and the Agricultural Wages Board under their respective statutes ${ }^{133}$ - can only be exercised for the benefit of those workers whose general remuneration has been fixed: statutory holidays are, so to speak, always "appurtenant" to general minimum remuneration, they cannot be granted "in gross." 134 Their duration must always be proportionate to the period of employment with the particular employer. ${ }^{135}$ The details of the regulations are of great interest both from a social and from a legal point of view. The provisions as to accrual and apportionment might have yielded a rich crop of legal intellectual exercises for which, however, fortunately, they failed to give opportunities in practice.

(5) The task of making the necessary investigations is entrusted to the councils and boards. They must give the public an opportunity (6), (7)

128. Wages Councils Act, 1945, §14; Agricultural Wages Act, 1948, §§6(5),

129. See for detailed information: Holidays with Pay. Collectrve Agreements Between Organisations of EMPLOYers and WorkPEOPLE (Min. Lab. 1939). See also Industrial Relations HandBook, Supp. No. 1, 22, 39 (1947). In May, 1947, there were in existence over 1100 collective agreements providing for holidays with pay. Altogether between 11 and 12 million wage-earners are entitled to paid holidays, either under collective agreements or under statutory orders.

130. Holidays with Pay Act, 1938, $1 \& 2$ GEo. VI, c. 70, § 4.

131. 1 \& 2 GEO. VI, c. $44, \S 2(1)(a)$ (now repealed).

132. 1 \& 2 GEo. VI, c. $70, \S 1$.

133. Wages Councils Act, 1945, § 10; Catering Wages Act, 1943, § 8; Agricultural Wages Act, 1948, \&3. Before 1947 all but three of the then existing 51 wages councils had exercised this power and fixed holidays. Catering wages boards have fixed holidays for workers in canteens and restaurants. See INDUSTRIAL RELATIONS HANDво0к, Supp. I, 37 et seq. (1947).

134. Terms borrowed from real property law where they are used in the law of easements.

135. Wages Councils Act, 1945, §10(2); Catering Wages Act, 1943, § 8(2); Agricultural Wages Act, 1948, § 3(3); Holidays with Pay Act, 1938, §§ 1(1), 1 (2). 
of inspecting the draft of any regulation they wish to make, and consider written objections raised or representations made within a prescribed period. ${ }^{136}$ Thus far the procedural principles applicable to all these bodies are fairly uniform. It is when we come to the legal effect of the action decided upon by the councils and boards that we see a difference between the Agricultural Wages Board on one side and the councils and boards established under the Wages Councils and Catering Wages Acts on the other. The Agricultural Wages Board does not only fix the standards it wishes to impose but makes the statutory orders by which they take legal effect: the minister is out of the picture altogether. The wages councils and catering wages boards, however, merely submit a "proposal" to the minister of Labour, and it is for the minister to decide whether or not these proposals are to be given the force of law by a "wage regulation order." While it is therefore the minister, and the minister only who, from a legal point of view, wields in these cases the power of delegated legislation and of imposing "statutory minimum remuneration," it is possible to exaggerate the practical importance of the difference between the system covering agriculture and that adopted in the other statutes. Under these statutes the minister cannot vary the regulations submitted to him by a council or board. All he has is a "veto" with the result that, in the last resort, he can paralyse the action of the independent bodies without being able to direct it. He must take the proposal submitted to him or leave it. In the latter case he may refer it back to the council or board with his observations and the council or board may (or may not) give effect to them in the form of amendments. Theoretically these proceedings may result in a deadlock; in practice this has not, in recent times, happened in fact. It remains true, however,-and this no doubt is the rationale of these provisions-that this distribution of functions between the independent boards and the civil service gives to the latter an opportunity for influencing and thus for co-ordinating the action of the various bodies. The Ministry of Labour is thus enabled to give effect-in certain limits-to a wages policy, a power withheld from the Ministry of Agriculture. ${ }^{137}$

(6) The jurisdiction of the various wage regulating authorities may easily overlap. Under the Wages Regulation and Catering Wages Acts this can be prevented by a cautious formulation of the Orders setting up the councils and boards and through the action of

136. Wages Councils Act, $1945, \S 10(3)$; Wages Councils Act, 1948, $\$ 6(2)$; Catering Wages Act, 1943, \$ 8(3); Ágricultural Wages Act, 1948, Schedule IV.

137. Wages Councils Act, 1945, $\S 10(7)$; Catering Wages Act, 1943. $\S 8(4)$; Agricultural Wages Act, 1948, \$3. See Selus, op. cit. supra note 14, at 137, 205-209. 
the Catering Wages Commission and of the central co-ordinating committees. Any difficulties that may arise in practice are removed by provisions which deprive the catering wages boards of any power to affect any worker in relation to employment subject to the jurisdiction of another wage regulating authority. ${ }^{138}$ If nevertheless clashes should occur, the problem would be solved by a general principle that the ruling most favourable to the worker prevails. ${ }^{139}$

\section{ENFORCEMENT}

What are the legal sanctions by which the statutory standards are enforced? In this respect more than half a century's experience of social legislation was brought to bear on the drafting of the Trade Boards Act, 1909, and a tri-partite scheme of sanctions, penal, civil, and administrative, was evolved which has stood the test of time and has not been essentially affected by recent developments.

(1) An employer who fails to pay the statutory remuneration or holiday remuneration or to allow the worker the statutory holidays (or, under the Catering Wages Act, intervals for meal or rest), is liable on summary conviction to a fine up to $£ 20$ for each offence, and, in agriculture, to a further fine up to $£ 1$ for each day on which the offence is continued after conviction. ${ }^{140}$ An agent of the employer who is guilty of the offence is similarly liable (e.g., a foreman) and the employer can exculpate himself by showing that the agent was exclusively responsible and that he himself had used all due diligence. ${ }^{141}$ The burden of proving compliance with the statutes rests on the employer. ${ }^{142}$

(2) The penal sanction by itself is a notoriously ineffective way of enforcing social legislation. Only by limiting the freedom of contract of employer and employee can the observance of any minimum

138. Catering Wages Act, 1943, §8(7).

139. Expressed in Wages Councils Act, 1945, $\$ 10(7)$; Catering Wages Act, 1943, $\S 8(7)$. It goes without saying that the existence of an Order does not deprive a worker of any rights he may have under an agreement or custom. $\$ 11(2)$ of the Agricultural Wages Act, 1948, which formulates this expressis verbis, was hardly necessary. All orders are minimum regulations.

140. Wages Councils Act, 1945, §11(2); Catering Wages Act, 1943, §9(2); Agricultural Wages Act, 1948, \& 4. For a description of the practical operation of the sanctions under the Trade Boards Acts, see SELLS, op. cit. sipra note 14, at 212-240.

141. Wages Councils Act, 1945, §16; Catering Wages Act, 1943, §12; Agricultural Wages Act, $1948, \S 10$.

142. This is expressly laid down in Agricultural Wages Act, 1948, §4(3), but would seem to be of general application. The leading case on the principle that the accused must disprove, negative facts "peculiarly within his knowledge" is Rex $v$. Turner, 5 M. and S. 206, 105 Eng. Rep. 1026 (K. B. 1816). 
standards be effectively secured. A contract of employment which is subject to a wages regulation or similar order takes effect as if the statutory remuneration, holidays, and holiday remuneration were substituted for any corresponding terms of the contract less favourable to the worker. ${ }^{143}$ A "back-pay" order up to two years can be made by a court of summary jurisdiction in the course of the criminal proceedings, or the worker can pursue his remedy in the civil court. ${ }^{144}$ Such civil proceedings may, on the worker's behalf and in his name, be instituted by the enforcement officer. ${ }^{145}$

(3) Experience has shown-the history of English Factory Legislation supplies the classical example ${ }^{146}$ - that without the existence of administrative machinery statutory standards can scarcely be enforced in practice. It is impossible, without a system of factory inspection, to translate into practice the law relating to health, safety, and welfare, and to the working hours of women and young persons. It is equally futile to try to impose minimum conditions as to wages, holidays and holiday remuneration without a permanent administrative machinery. Enforcement officers are therefore appointed under all these statutes ${ }^{147}$ endowed with far-reaching powers of inspecting and copying wage sheets, receipts and other relevant documents, examining workers as well as employers and their agents, entering premises, prosecuting offenders etc. Employers-except in agriculturemust keep records and see that, through posters and otherwise, their workers are informed of their rights. ${ }^{148}$ Non-compliance with these provisions, or with the legitimate requirements made by an enforcement officer is a criminal offense. ${ }^{149}$ It is also a criminal offence to obstruct an officer in the exercise of his powers or to produce falsified

143. Wages Councils Act, 1945, §11(1); Catering Wages Act, 1943, $\$ 9(1)$; Agricultural Wages Act, 1948, §11(1). The legal nature of compulsory implied terms in a contract has been repeatedly discussed by the Courts in a variety of contexts. See Bromford v. South Worcestershire Assessment Committees, [1946] 2 All Eng. 80 (K. B.); Gutsell v. Reeves, [1936] 1 K. B. 372; Powers v. Bawyer, [1945] 1 All Eng. 664 (C. A.).

144. Wages Councils Act, $\$ 11(2)$, (3), (4) ; Catering Wages Act, 1943, §9(3); Agricultural Wages Act, 1948, $\$ 4$. The limitation period for back pay orders in civil proceedings is that applicable to contractual, not that governing statutory claims. This was decided by the Court of Appeals in Gutsell v. Reeves, supra note 143.

145. Wages Councils Act, 1945, $\$ 17(5)$; Catering Wages Act, 1943, $\$ 13(4)$; Agricultural Wages Act, 1948, $\$ \$ 4,12$.

146. Hutchins \& HarRison, A History of Factory Legislation 36 et seq. (1911). The remark in the text refers to the Factory Act, 1833, which is the beginning of the development.

147. Wages Councils Act, 1945, §17; Catering Wages Act, 1943, §13; Agricultural Wages Act, 1948, $\$ 12$.

148. Wages Councils Act, 1945, $\S 15(1), 15(2)$; Catering Wages Act, 1943, $\S \S 11(1), 11(2)$.

149. Wages Councils Act, 1945, $\S 15(3), 17(6)$; Catering Wages Act, 1943, $\S \S 11(3), 13(6)$. 
records or wrong information. ${ }^{150}$ The fairly uniform system of administrative powers and corresponding duties evolved under these statutes is subject to a number of variations, some of which are of more than technical interest. Thus, the existence of the permanent Catering Wages Commission has made it possible to utilise the enforcement machinery for the purposes for which the commission was estabilshed. ${ }^{151}$ Moreover the policy of keeping the catering business under effective supervision has led to the further step-not taken elsewhere-of enabling the minister to impose on selected categories of employers the duty to register their businesses. ${ }^{152}$

\section{General Policy}

A study of the recent transformations of the law would be incomplete without a reference to the important new provision that individual employers are under an obligation to observe recognised terms and conditions, which-following a war-time order ${ }^{153}$ - has also been incorporated in the Wages Councils Act. ${ }^{154}$ This is not the place to discuss the great changes in the law of collective bargaining inherent in the adoption of this new principle. Suffice it to say that the pattern of law enforcement gradually developed since the First World War in connection with the fair wages clauses has now-at least temporarily-been extended to collective agreements in general: those agreements which, on both sides, are concluded by representative organisations, give rise to a legal obligation to observe their terms. ${ }^{155}$ They are not, however, directly enforceable in the courts. If a question arises as to whether any such "recognised terms and conditions" apply to a given contract of employment or whether they have in fact been observed by the employer, the jurisdiction of the Industrial Court can be invoked. ${ }^{156}$ That Court, acting, in fact, as a law-making body, then lays down the law of the trade by an award, the terms of which are legally enforceable and become-in certain circumstances retrospectively-compulsory terms of the contracts of employment to which they refer. But they are not by any means necessarily identical with those of the collective agreement whose alleged violation occasioned

150. Wages Councils Act, 1945, $\$ \$ 17(6), 18$; Catering Wages Act, 1943, $\$ \S 13(6)$, 14; Agricultural Wages Act, 1948, $\S 12(7)$.

151. Catering Wages Act, 1943, §13(5).

152. $I d . \S 7$.

153. Part III (Art. 5) of the Conditions of Employment and National Arbitration Order, S. R. \& O., 1940, No. 1305.

154. Wages Councils Act, 1945, $\$ 19$ and Schedule III.

155. Id. at Schedule III, No. 1.

156. Id. at Schedule III, No. 2. 
the proceedings. ${ }^{157}$ This new pattern of collective labour law does not form the subject-matter of this article and has been discussed elsewhere. It has, in the legal sense, nothing to do with minimum wage legislation, yet, in their operation, collective bargaining and minimum wage law are here, as everywhere, complementary institutions.

In fact, two streams of legislation have merged into one in the Wages Councils Act. The idea of collective bargaining dominates both the organisation of the wage fixing bodies and the definition of their functions-more so to-day than ever before. The extension of these functions so as to include the support of existing bargaining machinery is only one further step, and a natural step, in a development which was set in motion by the Trade Boards Act of 1909. At the same time, however, this method of strengthening the combined autonomous action of the two sides of industry has been supplemented by a novel-if perhaps temporary-method of procedure and indirect sanction, novel in its generality rather than in its conception. The law of recognised terms and conditions belongs to a legislative tradition which began shortly after the First World War, and the traces of which are scattered over the Statute Book in laws totally unconnected with minimum wage legislation. Now, however, the law seems to have reached a stage of greater maturity and systematic cohesion. Where collective bargaining is in danger of foundering because its institutions are not sufficiently strong or the standard of conformity with its terms is inadequate, the wages councils machinery will be set in motion. Where trouble arises because the terms of the agreements or the scope of their application is ambiguous or because, in isolated cases, they failed to secure observance, the law of recognised terms and conditions will come to the rescue. It will, so to speak, provide a remedy for the less serious or permanent, but, none the less troublesome, cases of disorder, while minimum wage law will remain in the background should the situation call for a stronger medicine.

When, in March 1945, Parliament passed the Wages Councils Act, many observers anticipated that there would be a wave of unemployment not long after the end of hostilities. The analogy of the post-1918 situation misled many economists and politicians in this country no less than in the United States. Hard industrial struggles following in the wake of a deflationary crisis were forecast, and it was

157. Id. at Schedule III, No. 3. These proceedings are inapplicable to workers subject to minimum wage laws. $\$ 19$ (1) Proviso. "Recognized terms and conditions" and statutory minimum remuneration are mutually exclusive. $C f$. $R$. v. National Arbitration Tribunal, [1943] 2 A1l Eng. 162 (K. B.), where a divisional court decided that the functions of a trade board and compulsory arbitration were so different that the existence of the former could not exclude the arbitration jurisdiction of the $\mathrm{Na}$ tional Arbitration Tribunal. 
feared that after the war many of the voluntary joint industrial councils which had come into being between 1940 and 1945 would disperse like many of their predecessors after $1918 .{ }^{158}$ It was to meet this anticipated situation-the concomitant of deflation and unemployment-that the Wages Councils Act was passed. The facts have so far belied these expectations. We are suffering from shortage of labour, not from unemployment, and, in a labour market in which frequently the demand exceeds the supply, minimum standards of labour conditions were not as much in need of legal protection as they were expected to be when the Act was passed. Nevertheless, the application of minimum wage legislation has been greatly extended under the Act. By a series of Orders the bulk of the retail distribution trade-more than a million workers-have, since the War, been brought within its scope. ${ }^{159}$ Irrespective of future economic developments, wages councils and similar statutory bodies are clearly destined to occupy an increasingly important place in British social and economic life.

158. See Mr. Bevin's speech in the House of Commons, 407 H. C. DEB. 78 (5th ser. 1944-45).

159. See, e. g., Wages Council (Retail Food Trades, England and Wales) Order, S. R. \& O., 1947, No. 1791; Wages Council (Retail Newsagency, Tobacco and Confectionery Trade, England and Wales) Order, S. R. \& O., 1947, No. 1792; Wages Council (Retail Newsagency, Tobacco and Confectionery Trades, Scotland) Order, S. R. \& O., 1947, No. 2313; Wages Council (Retail Bookselling and Stationery Trades, Great Britain) Order, S. R. \& O., 1947, No. 2312. 